\title{
Authenticity and other textual problems in Heroides 16
}

Ovid's double epistles are in many ways problematic for scholars. The collection of the Heroides as a whole is the most badly transmitted part of the Ovidian corpus, and by the time we reach the end of the collection we lack the evidence of increasing numbers of manuscripts, and at some points all of them: so the text is riddled with uncertainties. A major problem is caused by the couplets preserved in only a portion of the tradition: many of these are interpolations, but not necessarily all. In the case of poems 16 and 21 (the letters of Paris and of Cydippe respectively), we have lengthy passages transmitted only in late $15^{\text {th }}$-century printed editions and manuscripts derived from them. Above all, weighty arguments have been used to question Ovid's authorship not just of some of these poems, as is the case with the single epistles (Heroides 1-15), but all of them; and if they are by Ovid, when do they belong in his career as a poet, and how might answers to these questions affect our interpretation of what we read? These are the questions I shall be touching on in this paper. ${ }^{1}$

\section{A. Authenticity \& date of the double epistles}

I begin with 16-21 as a group: are they by Ovid? Reasons for doubt were codified by Lachmann, and the argument has gone back and forth ever since, with Courtney (against Ovidian authorship) and Kenney (for) giving the soundest accounts of the respective cases. ${ }^{2}$ The nub of the argument is that 16-21 have a series of stylistic details, in particular metrical licences and diction, that are otherwise absent from Ovid or occur only in exile, notably the following:

(i) Colloquial peream si only in Ovid at Ep. 17.183, 21.29; peream nisi only at ex P. 3.5.457, 4.12.43.

(ii) Stipulative use of sic $+u t / n e$ only at Ep. 17.165 (sic meus hinc uir abest ut me custodiat absens, 'my husband is absent from here on the basis that he guards me in absence'), 19.87-8, 181-2, 20.101-2; and Trist. 3.4.55-6.

\footnotetext{
${ }^{1}$ Besides the specific debts mentioned below, I must thank Stephen Oakley, Barrie Hall and Anna Ritchie, who suggested many helpful corrections and improvements; and acknowledge the contribution to this paper made by Adrian Hollis and the many students with whom we read some of the Heroides between 1998 and 2007. Adrian and I subsequently exchanged textual notes, which unfortunately we did not work up for publication before his death in February 2013; I hope they may still appear. I also benefitted from the responses of those who heard the paper in Cambridge, and an earlier version at Harvard (March 2005).

${ }^{2}$ Against Ovidian authorship: Lachmann 1876; Palmer 1898: 436-7; Courtney 1965, 1997-8; Beck 1996 (see also Knox 2000); Lingenberg 2003: 253-74 (arguing for an author different from that of the single epistles, also
} 
(iii) $q u i=$ quomodo, at 17.213. Kenney 1999: 406 is happy to see this as unique in Ovid; but as Michael Reeve pointed out (1973: 330, n.1) qui is found as a variant for quid in $M$ (the oldest and best MS) at Trist. 3.4.21 qui(d) fuit ut tutas agitarit Daedalus alas? ('How [or why] was it that Daedalus used his wings safely?') The two passages may be thought to support each other.

(iv) polysyllabic endings to the pentameter: 16.290 pudicitiae; 17.16 superciliis; 19.202 deseruit. Ovid keeps to disyllabic words in Amores, Ars, Remedia, and the single epistles.

The last group is clearly the most weighty: ${ }^{3}$ changes of diction may occur unnoticed by a writer, but so basic an alteration of metrical practice can only have been deliberate. The Tristia have 15 polysyllabic endings, but only proper names in book 1; Ibis two; the Epistulae ex Ponto have 30, including verbs. In the Fasti we find 5.582 fluminibus and 6.660 funeribus, and some ${ }^{4}$ have thought this evidence that Ovid relaxed his practice before exile, given that in his letter to Augustus from exile he mentions the Fasti as already composed (Tristia 2.549-52):

sex ego Fastorum scripsi totidemque libellos, cumque suo finem mense uolumen habet, idque tuo nuper scriptum sub nomine, Caesar, et tibi sacratum sors mea rupit opus. ${ }^{5}$

But this talks of a 12-book version; what got transmitted (and probably the only one published, for he speaks here only of writing, not reading) has only six books: like Ovid's career in Rome it is truncated, ${ }^{6}$ and it is shown to date from the years of exile by the specific reference at 4.81-4, by mention of events later than A.D. 8 (notably 1.285-6 on Germanicus' triumph over German tribes, awarded $1^{\text {st }}$ January 15 , and 1.637-50, on the opening of the temple of Concordia in A.D. 10), ${ }^{7}$ and more generally by the dedication to Germanicus. Courtney therefore argued that Fasti 5.582 and 6.660 should be attributed to the period of exile, and rightly drew attention to the context of 6.660, the exile of the tibicines, including at 666 exilium quodam tempore Tibur erat ('once Tibur was a place of exile'), far more pointed

not Ovid); for Ovidian authorship: Clark 1908 (with earlier bibliography); Tracy 1971; Kenney 1999; Lacki 2013.

${ }^{3}$ It was found decisive, e.g., by Mueller 1894: 29-31.

${ }^{4}$ So notably Kenney 1996: 21-3.

5 'I have written six books of Fasti and the same number again, and with its month each volume has its end, and this was recently written under your name, Caesar, and my fate interrupted a work dedicated to you.'

${ }^{6}$ See Ingleheart 2010, ad loc.

${ }^{7}$ See Green 2004, ad loc. 
language if written in Tomi. ${ }^{8}$

Courtney thus has a good case in arguing that the style of the 'double epistles' is such that, if by Ovid, they can only have been written in exile. ${ }^{9}$ But he concludes, 'It is inconceivable, and conceived by no one, that Ovid could have written poetry of this type at Tomis.' His bluff was already called by Reeve (1973: 330 n.1); ${ }^{10}$ and in the last 20 years scholars have started to read these poems as Ovid's erotica in exile: notably Barchiesi: ${ }^{11}$

The anomalies stop worrying us. The only price to pay would be to assume that Ovid is not very honest when he claims to have given up writing light elegiacs. Not a very high price, with a poet who claimed to have written a Gigantomachy ...

Those who stick to the traditional idea of the die-hard nequitiae poeta can appreciate the sting in the proemium to Paris' epistle ('here I am, and I am on fire, I cannot disguise my erotic flame, all too evident now') and the how-to approach to adultery in a Spartan setting, more than a millennium before the Ars and the leges Iuliae.

This is surely right. Stylistically the double epistles belong among the exile poetry, and with the later poems rather than the early Tristia. Though Ovid claims to be writing a Getan poem in praise of Augustus, he has actually gone back to the love poetry of his discreditable youth. And the later we place the poems, the less surprising is the failure to acknowledge them in other poems (though I suspect that the visit of Cupid to Tomi in ex Ponto 3.3 is supposed to do that). These may well be poems published posthumously: if the poet wanted recall, he could hardly allow such things to circulate under his name.

As a threesome these pairs of poems fit splendidly with what Ovid's concerns might be in writing love poetry in exile: like Ovid himself in Tristia 2 (and more generally) Cydippe has the best of the legal argument: she did not swear, she read iurantia uerba ('the words of an oath'). But in the end it comes to nothing, because she has the will of a deity opposed to her. Tomi is not so far from the Hellespont, as Barchiesi sees; ${ }^{12}$ at Abydos Leander writes to his beloved sitting on a rock, saddened by their separation, and able to go only with his imagination, and his letter, and not in person (Ep. 18.29-30):

rupe sedens aliqua specto tua litora tristis,

\footnotetext{
${ }^{8}$ The analysis has now been taken far further by Lacki 2013: 64-101.

${ }^{9}$ One might add that the proportion of hexameters ending in two monosyllables is higher even than ex $P$., otherwise the highest of Ovid's elegiac works: Lingenberg 2003: 270. Gaertner 2005: 37 finds similar results for monosyllables generally.

${ }^{10}$ Also, more tentatively, by Tracy 1971: 330 .

${ }^{11}$ Barchiesi 1996; see also (e.g.) Barchiesi 1995: 325; Ingleheart 2010: 21; and Lacki 2013.
} 
et, quo non possum corpore, mente feror. ${ }^{13}$

And Paris? Paris starts concerned about whether or not he should be writing a letter of this sort at all (Ep. 16.3-18):

Eloquar, an flammae non est opus indice notae, et plus quam uellem iam meus exstat amor?

ille quidem lateat malim, dum tempora dentur

laetitiae mixtos non habitura metus,

sed male dissimulo; quis enim celauerit ignem,

lumine qui semper proditur ipse suo?

si tamen expectas, uocem quoque rebus ut addam,

uror! habes animi nuntia uerba mei.

parce, precor, fasso, nec uultu cetera duro

perlege, sed formae conueniente tuae.

iamdudum gratum est quod epistula nostra recepta est: ${ }^{14}$

spem facit hoc recipi me quoque posse modo.

quae rata sit, nec te frustra promiserit, opto,

hoc mihi quae suasit, mater Amoris, iter;

namque ego diuino monitu (ne nescia pecces)

aduehor, et coepto non leue numen adest. ${ }^{15}$

This is not just Paris writing, but Ovid too: should he speak or is his amor already too well known (even without an informer, $3-4^{16}$ )? He would prefer it (i.e. love poetry) to remain hidden till times are unalloyed happiness (5-6); he's a bad dissembler, however, and his love

\footnotetext{
${ }^{12}$ For interest in significant proximity cf. 18.50: Leander notes the ominous closeness of the litus Icarium, well south in the Aegean.

${ }^{13}$ 'Sitting on some rock sadly I look at your coast, and I am carried in my mind where I cannot travel in body.' Mental travel as a theme of exile is explored by Lacki 2013: 161-83.

${ }^{14}$ Editors since Heinsius follow $\mathrm{P} \zeta$ in omitting est $(G \omega)$ and including the whole of the pentameter within the quod clause. But pleasure in the reception of the letter is better expressed as an independent thought before the separate hope of the pentameter.

${ }^{15}$ 'Am I to speak out, or is there no need of anything to reveal my well-known fire, and is my love more visible than I would wish? I would prefer that it be hidden until a time is granted that will not have fear mixed in with joy. But I'm bad at dissimulation: who could conceal a fire, which is always betrayed by its own light? But if you are waiting for me to add expression to the facts, I'm on fire! You have the words that reveal my soul. Spare me I pray, now I've confessed, and read through the rest not with a harsh expression, but with one that suits your beauty. It has long been a source of pleasure that my letter has been received; it gives me hope that I too can be received in this way. May the hope come true, and may the mother of Love, who sent me on this journey, not have promised you in vain, I pray; for (lest you sin unawares) I am brought here by divine instruction, and no light deity accompanies my undertaking.'

${ }^{16}$ For the importance of index, consider the implication of Tristia 3.6.11-16: if Ovid's bosom friend might have saved him had Ovid divulged the secret that got him exiled, he clearly did not reveal it to anyone and can only have been punished for failure to report what he had witnessed.
} 
betrays itself (7-10); he asks to be read non uultu ... duro (11), with an expression that fits the reader. Here we may note the use of conueniens in earlier contexts, which gives it a loaded and programmatic connotation here:

Arma graui numero uiolentaque bella parabam edere, materia conueniente modis. ${ }^{17}$ (Amores 1.1.1-2)

nec te purpureo uelent uaccinia fuco:

non est conueniens luctibus ille color. ${ }^{18} \quad$ (Tristia $\left.1.1 .5-6\right)$

inspice quid portem: nihil hic nisi triste uidebis,

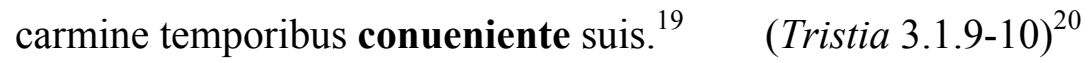

In short these are not tristia. In 16.13-14 the reception of the book gives hope that the writer too can be received - back in Rome: this is bolder than he gets in Tristia 1.1 or 3.1. Like Paris Ovid has been sent on his journey by a diuino monitu (17); he too is afflicted by a non leue numen. And wonderfully in the parenthesis ne nescia pecces, Ovid warns his female reader not to sin, or at least not to do so through ignorance!

Three further loaded terms from the exile elegies appear in 29-30:

nam neque tristis hiems neque ${ }^{21}$ nos huc appulit error:

Taenaris est classi terra petita meae. ${ }^{22}$

No grim sadness in Paris's letter, no storms either, no error. Such play can be found intermittently in Paris and Helen's letters, and in the two pairs that follow: 18.175-6, for example, is evocative of Ovid's own situation, separated toto orbe from the wife he so often writes to:

quid mihi, quod lato non separor aequore, prodest?

num minus haec nobis tam breuis obstat aqua?

an malim, dubito, toto procul orbe remotus

cum domina longe spem quoque habere meam. ${ }^{23}$

\footnotetext{
17 'Arms and violent wars in a weighty metre was I preparing to utter, the content suiting the metre.'

18 'Nor is the bilberry to cover you in its purple dye: that colour does not suit grief.'

19 'Inspect what I bring: you will find nothing here that is not sad, as the poem suits its circumstances.'

${ }^{20}$ Cf. also Tristia 5.1.5-6.

${ }^{21}$ nec Heyworth 2007: 231 n. 64.

22 'Neither a grim storm nor chance wandering brought me here: my fleet sought out Sparta.'

23 'What good does it do me that I am not separated by a broad ocean? Does this strait so narrow provide any less obstruction? I'm not sure whether I would prefer to be moved a whole world away and have my hopes as distant as my mistress.'
} 
and 20.7-8 presents him as a lover, but a husband, not an adulterer, and one who is owed to his wife by the forces that have separated them:

coniugium pactamque fidem, non crimina posco;

debitus ut coniunx, non ut adulter amo. ${ }^{24}$

So we have poems that are not just fine poems, but poems by Ovid that have a distinctive place in his oeuvre, and which comment on his situation as well as that of the characters in whose names they are written.

It is not by chance that I have begun this paper with a short consideration of the significance of that brief question 'why should Ovid not have composed Epp. 16-21 in exile?'. For this understated insight is a moment of typical acuteness and independence, and one that illustrates the profound literary effects of Michael Reeve's work as a textual critic; because it came with the authority of so learned a scholar, it gave Ovidians the confidence to follow through its implications. And they are enormous. We now have an Ovid who uses polysyllabic pentameter endings as markers of exilic composition, whether in the Fasti or the Heroides; and an Ovid who so far from being contrite and reformed in Tomi is still writing love poetry. What finer demonstration of independence and defiance could have been accomplished by the poet exiled for encouraging adultery in the Ars amatoria than the composition of an exchange of letters between the most famous pair of adulterers in ancient myth?

\section{B. The transmission of 16.39-144 and 21.145-248}

As a Cambridge undergraduate in the late 1970s I first heard of Michael Reeve as the author of articles on interpolation in Greek tragedy. But my earliest proper engagement with his writing came during Part II (1979-80), when studying the textual criticism of the double epistles with Ted Kenney. Reeve's 1973 article on the Heroides was, as he indirectly reveals in the preface to Manuscripts and methods (2011: VII), an early part of his move to becoming the doyen of the study of Latin textual transmission. To the Cambridge undergraduate the article was the source of wise corrections of Dörrie's edition and sharp new conjectures; but it also offered a challenge to Kenney's view that the disputed passages in 16 and 21 are Ovidian. Kenney's long article on the topic came out in the course of that year (1979), and I remember his saying that he expected a rejoinder from Reeve. That never came, and the

\footnotetext{
24 'I seek marriage and plighted troth, not anything illicit; I love as a destined husband, not an adulterer.'
} 
argument may seem to have been resolved in favour of authenticity. Yet there are questions raised by Reeve that create niggling doubts, in my mind at least; and what follows will scratch those doubts while engaged in a precarious attempt to stand on the shoulders of two giants.

After Dörrie's investigation of the transmission it became accepted that the only independent source for 16.39-144 and 21.145-248 was the Parma edition of $1477(\pi),{ }^{25}$ brought out by Corallus, who claims that the passages are additi ex antiquissimo codice. That is the view of editors such as Goold, Kenney, and Rosati, for example; and of Tarrant and Richmond in their surveys of the tradition. More recently, however, attention has been drawn to an incunable text, published in Treviso, and now only extant apparently in the library at Göttingen $(\tau){ }^{26}$ A bibliographical argument adduced by Engelbrecht (namely the font type) points to a date of about $1475,{ }^{27}$ and the textual evidence supports the idea that it is at least independent of the Parma edition:

\author{
16.42 cum т: $d u m \pi$ \\ 16.53 nemorosis $\mathrm{T}$ : nemorosus $\pi$ \\ 16.65 Pallade $\pi$ : pallide $\mathrm{T}$ \\ 16.81 Iouis $\pi$ : Iouem $\mathrm{T}$ \\ 16.91 nato т: nata $\pi$ \\ 16.92 festos $\mathrm{\tau}:$ festas $\pi$ \\ 16.131 tota $\pi$ : toto $\mathrm{T}$
}

16.136 intumuisse D.Heinsius: intonuisse $\pi$ : incaluisse $\mathrm{T}$ : intremuisse Francius: indoluisse uel intepuisse Heinsius

\title{
21.151 haec $\pi:$ hoc $\mathrm{T}$
}

\footnotetext{
${ }^{25}$ ISTC no. io00129000. See Dörrie 1960: 365-79; he found $\pi$ to be elsewhere dependent on the ed. princ. $(\alpha$, Bologna, 1471) and, for 21.15-146, ع (Venice, 1474).

${ }^{26}$ ISTC no. io00149400. For brief discussion, see Engelbrecht 1993a: 51 n.2; 1993b: 189. My first knowledge of $\mathrm{T}$, and its readings, came thanks to Marcus Deufert, whose friendship I owe to Michael Reeve.

${ }^{27}$ This is, however, about to be challenged by Wilfried Lingenberg (forthcoming). I am very grateful to him for sending me a draft, and also for corrections and information about $\tau$ (particularly the readings at 16.131 and 21.201). He dates the edition to 1478 on the basis of the known movements of the editor de Lisa, but only after ruling out a date before $\pi$ on the basis of Corallus' claim to have produced the first edition of the new lines. However, what Corallus says in full is Eiusdem heroidum liber unicus in quo plurimi uersus additi ex antiquissimo codice Presertim in epistola paridis ad helenam et in epistola Cydippes ad Acontium ('the same poet's single book of Heroides, in which a large number of verses have been added from an ancient manuscript, in particular in the letter of Paris to Helen and the letter of Cydippe to Acontius'): hardly an assertion of primacy (and he may simply not know about $\mathrm{T}$ ). In claiming that $\mathrm{T}$ here derives from $\pi$ Lingenberg treats all the improvements, including 16.136, as simple corrections and gives no weight to 21.233.
} 

21.166
amoma т: ammonia $\pi$
21.169 artus $\mathrm{\tau}$ : artis $\pi$
21.171 uideo т: uideor $\pi$
21.199 simulatur $\pi$ : similatur $\mathrm{T}$
21.201 tacito $\mathrm{T}$ : tacite $\pi$
21.202 mereatur $\pi$ : mercatur $\mathrm{T}$
21.205 (true reading uncertain) at mihi linga $\pi$ : at mihi lingua $\mathrm{\top}$
21.211 conualui т: cum ualui $\pi$
21.217 nес т: ne т
21.223 uincta Micyllus (iuncta cod. rec.): uicta $\mathrm{\tau}:$ uita $\pi$
21.233 nescioquem quantum Kenney: nescio quantum $\mathrm{T}$ : nescio quantum nunc $\pi$

Only three of the 6 places where $\mathrm{T}$ is wrong and $\pi$ is correct bear much weight: $16.81,131$, 21.202, the others being orthographical (21.199 similatur) or common substitutions (16.65 pallide, 21.151 hoc). In themselves these three do not show unequivocally that the Parma edition had independent access to the source; but as a large number of other errors go uncorrected, there is a limit to the amount of intelligent thought we can imagine going into the edition, and these cannot easily be reckoned conjectures. On the other hand, the Treviso edition in 10 places has Kenney's text against $\pi .{ }^{28}$ In addition, it apparently has readings that are false yet closer to the true text at 21.223 and 233. This last case is suggestive, because it looks as though Corallus, the Parma editor, has included an attempt to correct the defective metre. But the strongest sign of T's independence comes at 16.136. The text of $\pi$ reads $(16.135-6)$ :

ut uidi, obstipui praecordiaque intima sensi attonitus curis intonuisse nouis. ${ }^{29}$

It should have been obvious that the nonsensical intonuisse was caused by careless reminiscence of attonitus. ${ }^{30}$ Emendation should be sought by considering what verb Ovid

\footnotetext{
${ }^{28}$ At 16.104 T has hic, but (as Wilfried Lingenberg kindly pointed out to me) so does $\pi$, despite Dörrie's recording hinc. In this case the slip seems to have a concrete cause: I have a photocopy circulated by Ted Kenney in the 1970s where a mark like (but not identical to) the printer's abbreviation bar stands above the $i$ of hic. The copy I have consulted in the Bodleian has no such mark, so I assume it comes from a reader's alteration in one of those used by Dörrie (copies in Munich and London, according to 1960: 367).

29 'As I looked, I was paralysed and, thunderstruck, felt my heartstrings within thunder with fresh love.'

${ }^{30}$ Lingenberg claims that intonuisse is the kind of error that must have occurred in a manuscript. His draft article begins with a list of assimilation errors in the early editions (e.g. 12.87 sacris] thalamis ed. Bonon. 1471, and 16.257 ueteres] teneros ed. Rom. 1471, each corrupted from a stem in the previous verse): these he takes to be evidence of descent from lost manuscripts, but I believe it is a fallacy to think all typesetters worked word by
} 
might use to describe the effect seeing Helen has on Paris's heart. Although Dörrie, Goold, Rosati, Kenney, Michalopoulos all print intumuisse ('swell'), Daniel Heinsius's conjecture is a poor one: as Kenney admits, the verb is nowhere else used of the effect of desire, as opposed to pride or anger. ${ }^{31}$ Much the best of the possible readings is incaluisse ('grow hot'): Ovid has incalescere seven times of growing desire, including three other passages which describe love at first sight, e.g. Met. 2.572-4 (Neptune seeing the daughter of Coroneus, the future crow):

\section{nam cum per litora lentis}

passibus, ut soleo, summa spatiarer harena, uidit et incaluit ${ }^{32}$ pelagi deus. ${ }^{33}$

We should not bother about the greater distance from $\pi$ 's intonuisse, for we know that the origin of the second syllable is not misreading, but confusion with attonitus. And now we see that the source of this convincing reading is not conjecture, but a very early (perhaps the earliest) edition of the lines. The evidence is strongly for the independence of $\mathrm{\tau}$. But the Parma edition should continue to be cited too: there is no evidence to undo the claim that the lines derive from a manuscript; more to the point it has its own traces of independence. ${ }^{34}$

\section{The authenticity of 16.39-144 and 21.145-248}

As a result of this tenuous transmission the verses have often been dismissed as interpolations: for a clear statement see Reeve 1973: 334-7. Arguments for inauthenticity have been as follows:

(a) the anomalous length of 16 , if the tr passage is accepted.

(b) the fact that the passage in Paris's letter interrupts at a point where the sense seems to flow on: $16.38 / 145$;

(c) problems created for the plot of the pair of letters;

(d) particular anomalies;

word with no awareness of context. In the $15^{\text {th }}$-century Epistles of Sabinus $\pi$ itself has habiturum suum for habitura suum at 3.66 .

${ }^{31}$ Ovid uses the phrase intumuit Iuno at e.g. Met. 2.508, Fasti 6.487.

${ }^{32}$ The same phrase occurs of Echo (seeing Narcissus) at Met. 3.371, of Faunus (seeing Omphale) at Fasti 2.307; the other instances of incalesco of desire occur at Amores 3.6.26, Ep. 11.25, 18.42, Tristia 2.380.

33 'When, in my usual way, I was walking along the shore with slow steps on the top of the sand, the god of the sea saw me and grew hot.'

${ }^{34}$ According to the apparatus in Spieß 2012 the case is similar in the Epistles of Sabinus (where $T$ and $\pi$ are again the earliest copies): when they differ, $\mathrm{T}$ is correct ten times, $\pi$ twice; four times they are both wrong; 
I shall take these points in order, concentrating on Paris's letter, as far as details go, and not repeating much that Kenney's fundamental article seems to have right.

\section{(a) Length}

It is true that the length of 16 seems odd (at 378 verses, with lacunae to be added) against 1721 (with Helen's 268 the highest). ${ }^{35}$ However, Ovid is inconsistent in the length of paired poems in the Amores: thus the two Cypassis poems $(2.7,2.8)$ match at 28 lines, but one of the two poems on abortion (2.14: 44 verses) is more than $50 \%$ longer than the other $(2.13: 28)$, and if the 68 wheedling verses addressed to Bagous in 2.2 are rightly separated from the 18 of 2.3, we have a far more extreme case. The single epistles also vary considerably (Medea being 212, Penelope only 116). Here are the lengths of each poem, according to the Loeb numeration (which differs from other editions in some cases because of the exclusion of spurious or dubious opening couplets from the count), and ignoring possible interpolations and lacunae.

\begin{tabular}{|c|c|c|}
\hline 1 (Penelope): & 116 & \\
\hline 2 (Phyllis): & 148 & \\
\hline 3 (Briseis): & 154 & $752^{36}$ \\
\hline 4 (Phaedra): & 176 & \\
\hline 5 (Oenone): & 158 & \\
\hline 6 (Hypsipyle): & 164 & \\
\hline 7 (Dido): & 196 & \\
\hline 8 (Hermione): & 122 & 802 \\
\hline 9 (Deianira): & 168 & \\
\hline 10 (Ariadne): & 152 & \\
\hline 11 (Canace): & 128 & \\
\hline 12 (Medea): & 212 & \\
\hline 13 (Laodamia): & 166 & 858 \\
\hline 14 (Hypermestra): & 132 & \\
\hline
\end{tabular}

thrice the correct text is uncertain (but against Spieß I should read T's accendere at 2.87 and pecces at 2.97, the latter either a brilliant conjecture from de Lisa or a sign of independent authority).

${ }^{35}$ There is a subtle examination of the complexities by Lingenberg 2003: 253-8.

${ }^{36}$ The arrangement into books is speculative: see Pulbrook 1977; and on 16-21 Holzberg 1997: 94 . The standard length of the Ovidian book is 700-900 lines. 


$\begin{array}{lll}\text { P15 (Sappho): } & 220^{37} & \\ \mathbf{1 6} \text { (Paris): } & 272 / 378 & \\ \mathbf{1 7} \text { (Helen): } & 268 & 540 / 646 \\ \mathbf{1 8} \text { (Leander): } & 218 & 428 \\ \mathbf{1 9} \text { (Hero): } & 210 & \\ \mathbf{2 0} \text { (Acontius): } & 242 & >386 / 490 \\ \mathbf{2 1} \text { (Cydippe): } & 144+/ 248 & \end{array}$

It may be that other parts of 16 are interpolated and responsible for its being quite so long (207-14, e.g.); and 21, as it stands with the t passage accepted, is lacunose and must have exceeded 20 by more than the current count of 6 .

In addition, in her closing lines (17.265-8) Helen implicitly criticizes the length of Paris's letter: her hand is tired, and they can continue the conversation through her maids - and for ten long years in Troy, the reader realises.

hactenus; arcanum furtivae conscia mentis

littera iam lasso pollice sistat opus.

cetera per socias Clymenen Aethramque loquamur, quae mihi sunt comites consiliumque duae. ${ }^{38}$

Both Acontius and Cydippe end with comments on length - shortness suits her enfeebled state; and Leander jots down his 200 lines while the brave sailor waits on the harbour side.

One argument for authenticity has been understated: considered as interpolations, the two passages are of quite different kinds, the one a replacement of a lost ending, the other an additional embroidery in a passage that flows freely. What story can explain the interpolation in 21? The author introduces an etymological play (21.209-12):

mirabar quare tibi nomen Acontius esset:

quod faciat longe uulnus acumen habes.

\footnotetext{
${ }^{37}$ I am now inclined to think that the Epistula Sapphus is a basically Ovidian text, and that the oddities are to be attributed to corruption and interpolation: an analogous case to 16.39-144, 21.145-248. For example, at 113 sed postquam dolor increuit ('after the pain increased'), conjectured by Ramirez de Verger 2006, shows how convincingly 'the most striking' of the metrical anomalies may be removed (Tarrant 1981: 138); the verb is not certain (aduenit?). Besides Amores 2.18, for the positive case, see Rosati 1996 and Ramirez de Verger 2009, e.g.

38 'Enough. Now my hand is tired, let the letter that shares the secrets of my mind stop its furtive work. For the rest we may converse through my attendants Clymene and Aethra, the pair who are my companions and my guides.'
} 
certe ego conualui nondum de uulnere tali,

ut iaculo scriptis eminus icta tuis. ${ }^{39}$

Both acumen (punning on the senses 'sharp intellect' and 'stylus point') and iaculo

('throwing spear') pick up on the first syllable of the name of Acontius; ${ }^{40}$ this displays

Ovidian learning, ${ }^{41}$ and it is a variation of a play already made in Callimachus's Acontius \&

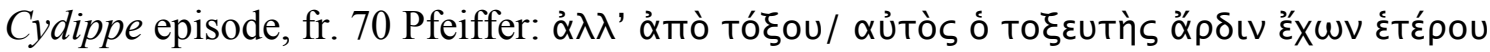
('but the archer himself receiving the point of an arrow from another's bow'). Such writing is surely ancient. We must assume total loss of the ending prior to the composition of 145-248; and given the undoubted antiquity of the basic composition (i.e. before 4th century, indeed as close to Ovid as possible), that looks an unlikely scenario, especially when one remembers that the passage has then to be transmitted independently right through to 1475 (and this without the benefit of a scholiastic tradition such as is responsible for the 'Helen episode' in Aeneid 2) - or else to imagine the new passage has been separately lost once again.

There is also the oddity that for those who do not accept the authenticity of $21.145-248$ the original length of 21 is quite unknown. We have to imagine an interpolator who carefully notes that 16 and 17 are of similar length (272 verses, and 268), and likewise 18 and 19 (218, $210)$, and so composes his replacement for the lost end so that the poem as a whole (248 verses) similarly matches the 244 of 20 . And this same interpolator (or are we to multiply them?) undoes his handiwork by creating the quite different expansion of 16 ! The issue of length is therefore as much a problem for the sceptic as for those who think the lines Ovidian, and should be disregarded as an argument.

\section{(b) Continuity}

Michael Reeve made a typically acute point about the manuscript text at the point where Tा add the section about the Judgement: it is an extraordinary coincidence that so coherent a sequence should have been produced by accident. ${ }^{42}$ The traditional text ran as follows $(16.35-8,145-8)$ :

te peto, quam pepigit lecto Venus aurea nostro;

te prius optaui quam mihi nota fores.

ante tuos animo uidi quam lumine uultus:

\footnotetext{
39 'I wondered why your name was Acontius: you have a sharpness that makes a wound from a distance. I at any rate have not yet recovered from such a wound, struck from afar by your writing, as if by a spear.'

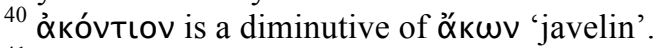

${ }^{41}$ Kenney 1996 ad loc. compares Virgil's acer Aconteus, Aen. 11.512-17.

${ }^{42}$ Rightly picked up as a key point by Lingenberg 2003: 255.
} 
prima fuit uultus nuntia fama tui.

credis et hoc nobis: minor est tua gloria uero,

famaque de forma paene maligna tua est.

plus hic inuenio quam quod promiserat illa

et tua materia gloria uicta sua est. ${ }^{43}$

However, there is one aspect of this sequence that has rightly alarmed scholars: the text of verse $38 .^{44}$ The transmitted text is unacceptable as a piece of Ovidian Latin: the repetition of uultus, with singular replacing the plural of the hexameter, lacks rhetorical point and elegance. The absence of a reference to Paris himself is also awkward. But none of the conjectures is a persuasive improvement. As Reeve points out, the regular idiom would give tulit uulnus the sense 'endured' rather than 'dealt a wound'. Kenney's conjecture avoids this problem, but only through substantial deviation from the paradosis (dedit uulnus ... mihi for fuit uultus ... tui), and as in other versions the epithet nuntia is left without point: what fama is not a 'messenger'? ${ }^{45}$ Watt's attempt seems to me the most plausible, but it is not clear what contribution to the argument would be made by the assertion 'Fama was the first messenger of you for us'.

I therefore propose another route out of the morass. This line is the first reference to fama in the poem; ${ }^{46}$ the text from verse 17 has concentrated on Venus's part in drawing the attention of Paris to Helen, on Venus's help in carrying him across the Aegean. fama is relevant in $145 \mathrm{ff}$, where Paris is flattering Helen by describing her beauty's unparalleled fame — and the way that beauty exceeds her reputation; but I suspect fama has been introduced into verse 38 precisely to bridge a gap between verse 37 and $145 \mathrm{ff}$ :

te peto, quam pepigit lecto Venus aurea nostro;

te prius optaui quam mihi nota fores.

ante tuos animo uidi quam lumine uultus:

credis et hoc nobis: minor est tua gloria uero,

\footnotetext{
43 'It is you I seek, whom golden Venus pledged for our bed; you I desired before you were known to me. I saw your features with my mind before I saw them with my eyes: Fama was the first messenger of your face. And you believe me when I say this: your glory is less than the truth, and Fama has almost been malicious about your beauty. I find more here than what she promised and your glory is conquered by the material on which it is based.'

${ }^{44}$ Sic PGw: prima mihi (V) uulnus nuntia fama tulit Palmer 1898; prima tulit uulnus nuntia fama tui Housman 1972: 412; prima dedit uulnus nuntia fama mihi Kenney 1996: prima fuit nobis nuntia fama tui Watt 1989: 667. The paradosis is defended by Ramirez de Verger 2007, usefully citing Lucretius 4.1033-34, but not dealing with the stylistic feebleness of the line.

${ }^{45}$ We may contrast 9.143-4 scribenti nuntia uenit/ fama, uirum tunicae tabe perire meae ('as I write a rumour has come with the message that my husband is dying thanks to the poison of the tunic I sent'), where nuntia evokes the tragic messenger who typically announces the death of Heracles to Deianira.
} 
famaque de forma paene maligna tua est.

plus hic inuenio quam quod promiserat illa

et tua materia gloria uicta sua est.

We should not be surprised that a reader faced with such a text, and the need to incorporate a pentameter to mend the defective couplet, should have written a line that employed uultus to pick up 37, and fama to look ahead to the gloria and fama of 145-6. But if the lost portion of text began with a pentameter, as my hypothesis thus holds, should we not see signs of that in the passage restored by тா?

Indeed we should and we do:

nec tamen est mirum si, sicut oporteat arcu,

missilibus telis eminus ictus amo.

sic placuit fatis. ... ${ }^{47}$

As my translation tries to show, there is to sicut oporteat arcu a kind of sense; but it cannot be the composition of anyone we might imagine to be the author of 16.39-144, and certainly not Ovid. A band of most distinguished Ovidians have tried to mend things, ${ }^{48}$ but even when Bentley and Watt stray far from the paradosis, they do not produce anything relevant to the context: why should Apollo suddenly turn up? why indeed Cupid? It is Helen herself who serves as the archer, but surely Ovid did not have his Paris describing her as the bow (as Housman's conjecture does, while employing a verb that it is not certain Ovid ever used in finite form ${ }^{49}$ ). The absence of plausible suggestions helps point to the cause: no Ovidian text lies behind the words. The line in $\mathrm{T}$ and $\pi$ is designed, yet again, to fill a gap: one that was now perceived between 38 and the first line of the restored passage, 40. So the original sequence ran as follows, I believe: ${ }^{50}$

te peto, quam pepigit lecto Venus aurea nostro;

te prius optaui quam mihi nota fores.

ante tuos animo uidi quam lumine uultus;

\footnotetext{
${ }^{46}$ But nuntia draws on the phrasing at verse 10: habes animi nuntia uerba mei.

47 'Nor is it any wonder if, just as ought to happen with a bow, I love struck from a distance by missiles. That's what the Fates resolved ...'

48 sicut opporteat arcu тп: sicut oportet ab arcu uel sicut oportuit actum Heinsius: sicut Apollinis arcu Bentley: sicut Amoris ab arcu van Lennep: sic cum polleat arcus Housman 1972: 412: si (sic fit Amoris ab arcu) Watt 1989: 66-7. For further bibliography, see Cucchiarelli 1996. He finds irony in Paris's mention of a bow at this point (cf. 363-4), but the essence of this is in verse 40.

${ }^{49}$ So Reeve 1974: 61. Contrast the participle pollens; but I suspect that at Ep. 8.34 we should read Bentley's plus patre, quo prior est ordine, pollet auus ('a grandfather has more sway than a father, before whom he belongs by rank', for P's impossible plus quoque prior est ordine posset auus): here at least the extension of regular diction would have substantial point.
} 
missilibus telis eminus ictus amo.

sic placuit fatis; quae ne conuellere temptes,

accipe cum uera dicta relata fide. ${ }^{51}$

The juncture at the end of the passage runs as follows (16.139-48):

si tu uenisses pariter certamen in illud,

in dubio Veneris palma futura fuit!

magna quidem de te rumor praeconia fecit,

nullaque de facie nescia terra tua est;

nec tibi par ${ }^{52}$ usquam Phrygia ${ }^{53}$ nec solis ab ortu ${ }^{54}$

inter formosas altera nomen habet!

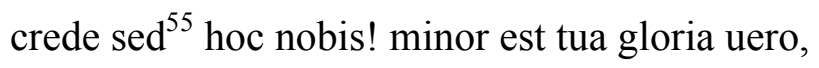

famaque de forma paene maligna tua est.

plus hic inuenio quam quod promiserat illa,

et tua materia gloria uicta sua est. ${ }^{56}$

The problems here are more discrete. In 145 both those who accept the passage and those who think it an interpolation can accept crede sed: and for trochaic imperative followed by sed, we can compare Trist. 3.7.40 finge sed, and Ex P. 2.2.124 adde sed. The preceding lines have been describing the fame of her beauty, and he asks for her to believe him as he turns to a greater flattery, the assertion that fame has understated her loveliness. Trickier is 143-4.

Correction of per to par is easy, and though we may be uncertain whether usquam Phrygia is superior to usquam Phrygiae (with an uncommon partitive genitive: see Deufert 2002: 504), the sense of the phrase is straightforward: 'anywhere in Phrygia'. But, as Kenney trenchantly argued (1970: 179-81), the phrase nec solis ab ortu needs to have its sense completed: in such polar expressions 'from east' is almost without exception matched with 'to west'. True, he acknowledges in the commentary that there is a possible parallel for such a unipolar

\footnotetext{
${ }^{50}$ Kenney 1996 notes on 16.37-8 that the motif of love by hearsay goes back to Hesiod, Eoeae fr. 199.2-3 M-W, but the link is with 16.37 , rather than the following lines.

51 'It is you I seek, whom golden Venus pledged for our bed; you I desired before you were known to me. I saw your features with my mind before I saw them with my eyes; I love struck by missiles from a distance. That's what the Fates resolved: lest you try to overthrow them, receive words narrated with true reliability.'

${ }_{53}^{52}$ par Naugerius: per тா.

53 usquam Phrygia тा: $u$ - Phrygiae Naugerius: omni in Phrygia Francius.

${ }^{54}$ sole sub omni Deufert-Gaertner-Winterbottom 2002: 505.

55 crede sed $5:$ credis et $\mathrm{PG} \omega$.

56 'If you had come to that contest along with her, the victory of Venus would have been in doubt. Great are the pronouncements rumour has made about you, and no land is ignorant of your appearance. Neither anywhere in Phrygia nor from the rising of the sun does another among beautiful women have a name equal to yours. But believe me when I say this: your glory is less than the truth, and Fama has almost been malicious about your
} 
expression at Ennius, epig. 1 (cited at Cicero, Tusc. Disp. 5.49):

a sole exoriente supra Maeoti' paludes

nemo est qui factis aequiperare queat. ${ }^{57}$

But this is a fragment, and a pentameter + hexameter may have been omitted, ${ }^{58}$ and in any case the fuller expression there makes the ellipse far easier. Kenney suspects a lacuna therefore. However, the gap is very hard to fill with words of substance; sole sub omni does not, I think, offer adequate sense ('nor in every clime' where we want 'nor in any ...'). I therefore incline to Kenney's alternative suggestion: inter formosas is superfluous here and rather odd; and it might well have arisen from a gloss or an attempt to mend damage incurred by the last line of the lost passage. Let us read, exempli gratia,

nec tibi par usquam Phrygia nec solis ab ortu

solis ad occasus altera nomen habet! ${ }^{59}$

The phrasing of the end of the hexameter and the start of the pentameter is then identical to that at Ex P. 1.4.29-30 quem solis ab ortu/ solis ad occasus utraque terra tremit ('before whom each continent trembles from the rising of the sun to its settings').

I should briefly add that the sequence at $21.144 / 145$ is unproblematic. Verse 145 takes a striking but appropriate turn immediately: Cydippe suggests the immense power that Acontius' trick gives him if repeated with others.

\section{(c) Plot}

(i) There is a mismatch, rather more serious than Kenney 1979: 407-9 allows, between 16.4950 and 17.239-40: if Paris has told Helen that a prophet explained Hecuba's dream as a prognostication of Troy's destruction by fire, she should not be attributing the story to others, as she does with ferunt (17.237-40):

fax quoque me terret, quam se peperisse cruentam

ante diem partus est tua uisa parens;

et uatum timeo monitus, quos igne Pelasgo

Ilion arsurum praemonuisse ferunt. ${ }^{60}$

\footnotetext{
beauty. I find more here than what she promised and your glory is conquered by the material on which it is based.'

57 'From the sun rising over the marshes of Maeotis there is no one to match his [or my] deeds.'

${ }^{58}$ So Skutsch apud Walbank 1967: 57-8.

59 'Nor anywhere in Phrygia, nor from the rising of the sun to its settings does another girl have a name that matches yours.'

60 'The torch terrifies me too, which your mother dreamt she gave birth to, covered in blood, before your birth; and I fear the warnings of the seers, whom they report to have warned Ilium will burn with Pelasgian fire.'
} 
Verses 237-8 of Helen's letter recount the dream, as do 43-6 of Paris's, in terms clearly alluding to the version in Ennius's Alexander: ${ }^{61}$

matris adhuc utero partu remorante tenebar; iam grauidus iusto pondere uenter erat. illa sibi ingentis ${ }^{62}$ uisa est sub imagine somni

$\underline{\text { flammiferam pleno reddere uentre facem. }}$

territa consurgit metuendaque noctis opacae uisa $^{63}$ seni Priamo, uatibus ille refert. arsurum Paridis uates canit Ilion igni pectoris, ut nunc est, fax fuit illa mei.

forma uigorque animi, quamuis de plebe uidebar, indicium tectae nobilitatis erat. ${ }^{64}$

However, it is 49-50 that makes for awkwardness when set against Helen's ferunt. But this couplet is in many ways suspect in itself, and the correct solution may be to delete these two lines, and not the whole of 39-144. In the first place, the move from plural uatibus to singular uates is most inelegant: Kenney suggested a conjectural way round this difficulty (canit Aesacus), with a gloss uates extirpating the proper name Aesacus, Priam's prophetic son; but there are further difficulties. Most seriously, as was already noted by $16^{\text {th }}$-century commentator Micyllus, there is a very awkward prolepsis in the naming of Paris: if the prophet predicts that the flame of 'Paris' will burn Troy, his parents simply select a different name. In the pentameter we have the phrase ut nunc est, which appears also at Ep. 17.169 and 19.127. Otherwise it occurs in verse only at Terence, Adelphoe 399 ('as he is now') and Horace, Serm. 1.9.5 ('as things now stand', as six times in Cicero's letters): neither sense would work here.

The reason for the interpolation is clear: something has dropped out of the text between

\footnotetext{
${ }^{61}$ Ennius, Alexander 41 Jocelyn (from Cic. Diu. 1.67; underlining marks verbal links): adest adest fax obuoluta sanguine atque incendio ('here, here is the torch covered in blood and fire'); Alexander 50-1 Jocelyn (from Cic. Diu. 1.42): mater grauida parere se ardentem facem/ uisa est in somnis Hecuba ('my mother Hecuba when pregnant dreamt she gave birth to a burning torch').

${ }^{62}$ Adrian Hollis suggested ingentis during our Oxford classes, comparing FRP 22 (Calvus fr. 11) and Martial 12.18.13; ingentem тா: urgentis Palmer: mirum uel in partu Bentley: ingesti Hall 1990: 285. Skutsch 1985: 297 undoes the notion that 'two unconnected adjectives with one noun' is characteristically Ennian.

${ }^{63}$ Perhaps ipsa: an expressed subject would make it easier to read the ỏmò кoเvoũ construction; cf. Tristia 1.11.43-44 uincat hiems hominem. sed eodem tempore, quaeso, / ipse modum statuam carminis, illa sui ('Let the storm overcome the man. But at the same moment, I beg, may I put an end to the poem and the storm to itself'). 64 'I was being held in my mother's womb, my birth delayed; her belly was already swollen with the due weight. In a vision of mighty sleep she dreamt she delivered a flaming torch from her full belly. Terrified she rises and reports the fearsome sights of the dark night to old Priam, he to the seers. A seer prophesies that Ilium will burn
} 
verse 48 and the account of Paris's early years as a shepherd (or anything but a shepherd, as he will present it). Verses $49-50$ are a rather feeble attempt to mend the truncated nature of the dream narrative. What I imagine to have been lost is a statement that the uates advised that the child should be exposed (cf. Ennius, Alexander 60 Jocelyn); followed by an account of how he was taken up to Ida, but survived. The basis for the warnings of the prophets is not germane to Paris's case here. And the fine if grim point made by the equation of fires of love and destruction is used at 123-6 in his reinterpretation of his sister Cassandra.

Kenney 1996: 90 takes the phrase ut nunc est to mean 'as it now appears', but without any explanation for how the verb gets this extension of sense. Of the other Ovidian cases, nothing else is out of order at $19.127 .{ }^{65}$ But 17.169 occurs in another context multiply suspect (163-74).

uela quidem Creten uentis dedit ille secundis;

sed tu non ideo cuncta licere puta.

sic meus hinc uir abest ut me custodiat absens -

an nescis longas regibus esse manus ${ }^{66}$

fama $^{67}$ quoque est oneri: nam quo constantius ore

laudamur uestro, iustius ille timet.

quae iuuat, ut nunc est, eadem mihi gloria damno est,

et melius famae uerba dedisse fuit.

nec, quod abest hic me tecum, mirare, relicta;

moribus et uitae credidit ille meae.

de facie metuit, uitae confidit; et illum

securum probitas, forma timere facit. ${ }^{68}$

In 163-6 Helen discusses her husband's absence: this gives them a little licence to play, but he watches her through the eyes of others: kings have a long reach. In 171 she resumes thoughts about being left behind by explaining how her past behaviour has given Menelaus confidence, despite the fears her beauty might have been expected to rouse in him. In

with the fire of Paris - that was the torch in my heart, as it is now. Though I seemed to be from the common folk, my stature and the quickness of my mind were a sign of hidden nobility.'

${ }^{65}$ But Dilthey's utcumque est would have rather more point; and the text runs well without the couplet.

${ }^{66}$ 'With a following wind he has set sail for Crete; but you should not therefore think everything is possible. My husband is absent from here on the basis that he guards me in absence - or do you not know that kings have long arms?'

${ }^{67}$ forma Bentley (тò kó́ $\lambda \lambda$ os Plan.).

${ }^{68}$ 171-4: 'And do not be surprised that he has gone and left me here with you: he put his trust in my character and behaviour. He is fearful about my beauty, confident about my behaviour; virtue makes him carefree, appearance makes him anxious.' 
between we have two couplets that contribute nothing to the sequence: 'My reputation (or beauty) also is a burden; for the more we are praised by the mouths of you men, the more justly he feels fear. The fame which pleases, as things stand now, is also harmful to me, and it was better to have cheated Fama.' Helen's prospects with Paris have manifestly not been harmed by the way men talk about her, for Menelaus has gone off, trusting the two of them (and iustius ille timet will be contradicted for the past by 172-4); the only sensible point would be if she feared that in Crete talk of her beauty might alarm Menelaus and send him home early: but nothing clarifies this point, and one would have expected a hypothetical statement, rather than the assertion we have here. In 169 iuuat is the wrong tense, and obscures the function of ut nunc est; the idea of cheating fama is a very strange one, especially when it involves the phrase uerba dedisse to express the notion of keeping fama silent: contrast 21.121, which has a far more pointed play on uerba dare. It is hard to believe that these lines are written by the same author as the rest of the poem.

In the light of these two instances the phrase $u t$ nunc est could be characterized as a meaningless space-filler, marking the style, not of Ovid in one short period, but of a collaborative reader. ${ }^{69}$

(ii) At 16.93-100 Paris presents himself as a male equivalent to Helen, a cause of desire among maidens, the daughters of kings and chieftains, and even nymphs — but all were forgotten when Venus gave him hopes of marrying Helen (93-100):

utque ego te cupio, sic me cupiere puellae; multarum uotum sola tenere potes. nec tantum regum natae petiere ducumque,

sed nymphis etiam curaque amorque fui. quas super Oenonem facies mutarer in orbem ${ }^{70}$ nec Priamo est a te dignior ulla nurus. sed mihi cunctarum subeunt fastidia, postquam coniugii spes est, Tyndari, facta tui. ${ }^{71}$

\footnotetext{
${ }^{69}$ For the concept, see Tarrant 1987: 294-7.

${ }^{70} \mathrm{Sic}$ тा: quas super Oenone facie memorata per orbem or quas tamen Oenone facie supereminet omnes ('sed hoc est hariolari'!) Burman: quas super Oenones faciem mirabar, in orbe Ehwald: quam super Oenones faciem mirarer? in orbe Palmer: quam super Oenonen toto mirarer in orbe Diggle 1967: 139. The couplet was omitted by many of the older editors, including Burman.

$71^{\prime}$ 'As I desire you, so girls have desired me; you alone can have the wish of many. It was not only the daughters of kings and princes who sought me, but I have been the love and care of nymphs too. What beauties above Oenone should I be changed to the world? [nonsense, as transmitted] There is none more worthy as a
} 
The rhetoric of these generalities is damaged by the specific reference to Oenone: the last thing Paris wants to do here is to tell Helen that he has been married before (98); and the rhetorical question of 97 is inept in expression, however amended. I imagine the original text read mirarer in orbe: 'What beauties in the world should I admire above Oenone?' The couplet is an interpolation designed to fill in information, drawn most obviously from $E p .5$, but only implied originally. Mythological embroidery is one of the most frequent causes of interpolation in the Heroides: there are good grounds for suspecting these passages, for example: 8.67-72, 9.85-100, 9.131-4, 16.207-14; 17.59-60. Thus we should not be troubled by the way in which Helen mentions Oenone at 17.195-8:

tu quoque dilectam multos, infide, per annos

diceris Oenonen destituisse tuam.

nec tamen ipse negas; et nobis omnia de te

quaerere, si nescis, maxima cura fuit. ${ }^{72}$

diceris (like ferunt at 240) looks wrong if Paris himself has mentioned Oenone. But if we omit 16.97-8 on internal grounds, Helen's nec tamen ipse negas picks up nicely from Paris's quiet reference to nymphs in 16.96, and the rest of the couplet shows how Helen has gathered her further information (apparently by reading Heroides 5). One problem we have to face if we delete 16.97-8 is we are left with two adjacent verses beginning with sed; Ovid only does this when there is a pointed anaphora. Of course opening monosyllables are often corrupted. $^{73}$ at (Itali) is an easy substitution; but we might also consider ei mihi: cf. 339 for the use of this phrase to give an emotional charge to an otherwise unemotional context.

\section{(d) other textual oddities and positive signs}

I am therefore confident that the two passages are (for the most part) by the same author as the rest of 16-21, i.e. Ovid: Reeve was right, I believe, to worry about the continuity at $38 / 145$ and about the Latinity of various lines, such as $39,97,144$, but these problems should be confronted on the basis that we are attempting to discover an Ovidian original. Not surprisingly text so tenuously transmitted has suffered internal corruption, and Kenney's article and edition do much to restore order; but more can still be done, for example at 16.7586:

\footnotetext{
daughter-in-law for Priam save you. But disdain of all came over me once the hope was created of marrying you, Helen.'

72 'You too, unfaithful man, are said to have abandoned your Oenone, whom you loved for many years. Nor do you deny it; if you didn't realise, it has been a great concern of ours too to find out everything about you.'

73 'Kenney's Law': see e.g. Heyworth 2007: 410.
} 
uincere erant omnes dignae, iudexque querebar

non omnes causam posse tenere ${ }^{74}$ suam.

sed tamen ex illis iam tunc magis una placebat,

hanc esse ut scires unde mouetur amor. ${ }^{75}$

tantaque uincendi cura est, ingentibus ardent

iudicium donis sollicitare meum.

regna Iouis coniunx, uirtutem filia iactat;

ipse potens dubito fortis an esse uelim.

dulce Venus risit 'ne'c ‘te, Pari, munera tangant

utraque suspensi plena timoris' ait;

'nos dabimus quod ames, et pulchrae filia Ledae

ibit in amplexus pulchrior ipsa ${ }^{76}$ tuos. ${ }^{, 77}$

Ovid has ardere followed by an infinitive at Met. 5.164-6 tigris ut ... duorum/ ...

armentorum/nescit utro potius ruat et ruere ardet utroque ('as a tigress does not know which of two herds to attack rather and burns to attack both'); but is the sense appropriate in 79-80? One burns with lust, or anger, or hunger (like the tigress), and, if the stakes are high enough, with desire to win. But do even goddesses burn to corrupt the impartiality of their judge? A verb Ovid repeatedly uses with an infinitive, especially to mark the point to which actions are pushed, is audere, and I suggest audent is what was originally written here: 'such is their desire for victory, they dare to corrupt my judgement with major gifts'. Compare two other passages for the phrasing: Fast. 3.483-4 ausus es ante oculos adducta paelice nostros/ tam bene compositum sollicitare torum? ('have you dared to parade a mistress before my eyes and to upset so settled a marriage bed?') Ep. 17.3-4 ausus es hospitii temeratis aduena sacris/legitimam nuptae sollicitare fidem ('as a stranger you have dared to violate the sacred rules of hospitality and to tamper with the formal oath of a bride') ${ }^{78}$ In each case sollicitare points to the upsetting of a legally established situation (cf. iudicium at 16.80). Particularly

\footnotetext{
${ }^{74}$ posse tenere Francius: uincere posse Tr; see Kenney, but note, however, Calp. Sic. 1.45 causam uicit.

75 77-8 del. Bentley: que works more easily if it links 79 directly to 75-6 (and Venus's beauty is not directly relevant to Paris's case here).

${ }^{76}$ ipsa ed. Bersmanni margo: illa $\mathrm{T \pi}$.

77 'All deserved to win, and as judge I complained that not all could maintain their suit. Still, of the three one was already pleasing more, so that you might know she is the origin of love. And there was such concern for victory, they burn to pervert my judgement with enormous bribes. The wife of Jupiter speaks of kingdoms, his daughter of courage; I am uncertain in myself whether I wish to be powerful or to be brave. Venus laughed sweetly and said, 'Paris, don't be affected by gifts both full of anxiety and fear. We shall give you something to love, and the daughter of beautiful Leda, more beautiful herself, will fall into your arms.'

${ }^{78} \mathrm{Cf}$. also Tib. 1.9.54 te qui puerum donis corrumpere es ausus ('you who have dared to corrupt my boy with gifts').
} 
seductive is the presence of the phrasing in the opening lines of Helen's reply: she shows how carefully she has read the letter from her lover, and throws his corrupting words back at him.

That gives us one positive hint that 16.40-144 belong; analogous is the relationship noted by Kenney 1996 between 16.41 ne <fata> conuellere temptes ('lest you overturn the fates') and Helen's echo in 17.111 desine molle, precor, uerbis conuellere pectus ('please stop overturning my delicate heart with your words'). ${ }^{79}$ The account of the Judgement in 16.59-88 provides details that Helen's letter exploits in the brief reworking at 17.115-34; but the author of the passage in 16 has not slavishly imitated any phrasing. ${ }^{80}$ Such things may be due to chance, or careful composition by an imitator; far more significant is a very subtle point that Kenney rightly stressed (1979: 396), the presence in these passages of the compendious nec $=$ et 'non ...' $(16.83,21.222)$, otherwise found only in Metamorphoses and Fasti, and not in any other authors. ${ }^{81}$ One may observe too that between 39 and 144 would be a very strange place for an interpolator to add a passage, if (as is credible in itself) someone wanted to introduce into Paris's letter a narrative of his encounter with the goddesses.

It is also striking that, as we have seen, both passages dealing with Hecuba's dream (16.43-6; 17.237-8) show knowledge of Cicero's de Diuinatione, if not Ennius' original Alexander. We have indication of an early date for the composition of 16.101-2

te uigilans oculis, animo ${ }^{82}$ te nocte uidebam lumina cum placido uicta sopore iacent. ${ }^{83}$ in the imitation at Anth. Lat. 702 (ascribed to Petronius):

te uigilans oculis, animo te nocte requiro uicta iacent solo cum mea membra toro.

uidi ego me tecum falsa sub imagine somni. ${ }^{84}$ somnia tu uinces, si mihi uera uenis. ${ }^{85}$

\footnotetext{
${ }^{79}$ Mazurek 2006 makes subtle further points about the contribution of 16.39-144, though some are based on lines I would discard.

${ }^{80}$ See further e.g. Werfer 1814: 512, and Kenney 1979: 402-7, who notes that the certainly spurious couplet (cum Venus et Iuno Pallasque in uallibus Idae/ corpora iudicio supposuere meo, 'when Venus, Juno and Pallas exposed their bodies to my judgement in the glens of Ida') added by some late MSS after 16.168 is based on 17.115-20.

${ }^{81}$ This develops from Ovid's earlier innovation in attaching -que to a word in direct speech, e.g. at Am. 1.1.23 'quod'que ... dixit (McKeown 1989), Ep. 17.159 'res'que ... ait (Kenney 1996).

${ }^{82}$ Kenney 1996 prints Bentley's oculis animi; but the imitation changes the balance of evidence in favour of retaining the transmitted text: the contrast is between the waking and the sleeping vision, úm $\alpha \rho$ and óv $\alpha \rho$ (a point I owe to Adrian Hollis); see also Rosati 1990: 171-4, and Werfer 1814: 512, who compares 7.25-6.

83 'You I was seeing with my eyes when awake, you with my mind at night when eyes lie overcome by calm sleep.'

${ }^{84}$ Kenney 1979: 400 notes the further echoes of 16.45 sub imagine somni and 17.45 falsa sub imagine.
} 


\section{Final thoughts on transmission and method}

There is at least one further puzzle: where do the passages come from? Commonly I suspect it is believed that some stray pages of an old manuscript were found: passages of 105/6 lines and 104 lines could each come from a single bifolium, with approximately 26 verses per page. ${ }^{86}$ These would have been lost from the middle of two separate gatherings in the archetype, perhaps followed by the loss of the first two folios of the final gathering with serious damage to the final page of the penultimate (to account for the thin transmission of 21.13-144). This would make the final gathering a ternion (i.e. three sheets bound together). Scribes often reduce the size of final gatherings when they see how much text remains to be written; in this case two sheets would just have been sufficient (and conceivably he might have used two singletons and a bifolium). However, to reconstruct a single manuscript on this basis is, if not impossible, by no means easy: it requires us to assume one or more of the following: that a considerable number of couplets stood in the margin, or were subsequently lost; sizeable interstices between poems; or high levels of inconsistency in the quiring or the number of lines on a page. ${ }^{87}$

There is, however, no need to assume that 21.144-248 took up a complete opening, for this is the end of the text. So we might alternatively suppose that the 132 verses from 21.13 144 come from the first two folios of a gathering (33 verses a page), and 145-248 were on the middle sheet; that would leave 1184 (+ possible interstices) from 16.145; if we suppose that pages were written with variable numbers of lines between 26 and 33, that might well space 1184 verses over 38 pages (just over 31 verses a page: we might imagine an increase from $26 / 27$ to 31 to 33 in the final gathering as the scribe becomes more anxious about parchment: compare $\mathrm{N}$ of Propertius, which increases from 27 to 32). This would allow 16.40-144 to have sat in the middle of a quaternion, followed by two others before the final ternion.

But whatever the reconstruction, we need to ask how the editors knew where to add 16.39/40-144. Given the continuity between 38 and 145, a position between 148 and 149

\footnotetext{
85 'You I seek with my eyes when awake, you with my mind at night when my limbs lie overcome on an unshared bed. I have seen myself with you among the deceitful images of sleep. You will surpass my dreams, if you come in reality.'

${ }^{86}$ Here again I am grateful to Marcus Deufert, who encouraged me to pursue this line of enquiry. For awareness of the possible importance of multiples of c. 26 verses, see already Mueller 1894: 285, who adduces the 100 lines of the Medicamina faciei femineae as an immediate parallel.

${ }^{87}$ See Reeve 1973: 335, n. 2 on one misguided attempt at such a reconstruction.
} 
would have made an easier home: ${ }^{88}$ in particular qui nouerat omnia, Theseus would pick up well from the assertion of Helen's unparalleled beauty in 143-4. Moreover, when this point is added to Corallus's words 'uersus additi ex antiquissimo codice', it does look as though the source is a complete manuscript. Of course that only pushes the argument back a stage, but we can construct a narrative that has a scholar discovering the lost passages in a complete manuscript, recognizing them as new and having time to copy only these, on pages that he then stuck into an existing, previously unexceptional, manuscript, with clear indication of where they were to be introduced. Such a story would explain why Tா apparently lack other exceptional readings.

Courtney 1997-8: 162 sets out what he sees as the ground rules for conducting debates on authenticity:

The advocate of spuriousness must refrain from objecting to improvements in the transmitted text which can be accounted for by normal processes of textual corruption (e.g. at 16.38, 17.119, 18.2 and 160, 20.36; Beck 86-87 discusses 18.76 in this spirit), even if, as at 18.160 , the intent and effect of the conjecture are to introduce Ovidian idiom. The advocate of genuineness should, however, be wary of emending things just because they seem un-Ovidian, a process which amounts to deleting evidence.

The opening of the second sentence, where Courtney announces the rules for his opponents, seems reasonable: it is right to be wary. But the process of emending, even when it involves deletion, should not be described with an emotive term like 'deleting evidence'. Firstly this is because the evidence will not be deleted, unless someone burns the Treviso and all the Parma incunables and all the photographs and all the collations of them; but more seriously because (to quote now from the first sentence) the 'normal processes of textual corruption' include things that repeatedly turn Ovidian Latin into un-Ovidian Latin. And thus in the particular case at issue there is no historical reason for expecting the Tा passages to be any less liable to corruption and indeed interpolation than the rest of the Heroides, which are the most corrupt part of Ovid's corpus, fully repaying the critical attentions of scholars such as Heinsius, Bentley, Housman - and Reeve. ${ }^{89}$

\footnotetext{
${ }^{88}$ Those who think 39-40 are original might treat this as a serious conjecture.

${ }^{89}$ I think particularly of the conjectures iusso at 1.37 (Kennedy 1984: 418 n. 14), hoc exemplo at 17.97, et ... habe at 17.115, nescioquo ... hebet (after Heinsius) at 19.192.
} 